ARTICLE

\title{
Education during and after the pandemics
}

\author{
Candido Alberto Gomes ${ }^{a}$ \\ Susana Oliveira e Sá ${ }^{b}$ \\ Enrique Vázquez-Justo ${ }^{c}$ \\ Cristina Costa-Lobo ${ }^{d}$
}

\section{Abstract}

Education in the pandemic time often received an improvised and non-realistic treatment. This is a major reason for planning now the post-pandemic period. According to the literature and document analysis, social, international and intra-national fractures, detected by current theories, were largely exposed. Besides Covid-19, other crises developed, such as impoverishment and violence. In general, the population has had losses; however, the least privileged have been subject to a greater burden. Countries cannot repeat past mistakes or try to restore Education as it was before, since the circumstances are different. Furthermore, in addition to the learning deficit, it is urgent to recover Education in its multiple ends and goals. Therefore, it is important to support educators, students and families, with a specific focus on the underprivileged, counting on the participation of the social forces of community and society.

Keywords: Education Inequalities. Pandemic. Health and Education. Human Personal Development. Family.

This is an essay about international educational problems caused by the pandemic, particularly focusing on common features and some basic directives for the restablishment of Education at least in most countries. We selected relevant articles from Scholar Google, Web of Science and Scielo. Documents in general were detected by Google. Newspapers selected were those with more frequent news

\footnotetext{
a Centro de Investigação, Desenvolvimento e Inovação do Instituto de Estudos Superiores de Fafe. Fafe, Portugal.

b Centro de Investigação, Desenvolvimento e Inovação do Instituto de Estudos Superiores de Fafe. Fafe, Portugal.

c Centro de Investigação, Desenvolvimento e Inovação do Instituto de Estudos Superiores de Fafe. Fafe, Portugal.

d Centro de Investigação, Desenvolvimento e Inovação do Instituto de Estudos Superiores de Fafe, Fafe, Portugal. / Centro de Estudos Organizacionais e Sociais do Politécnico do Porto, Porto, Portugal.
} 
in Education, accompanied daily since March 2020. Keywords most frequently used were: pandemic, Education, learning, schools, colleges, and universities.

In several countries and situations, Covid-19 has been denied, swept under the carpet and treated impromptu, implying the cost of lives, labor and a flow of wide and deep repercussions. As if science did not foresee the plurality of waves of contamination, in certain places it also seems to lack the breath to overcome them. These experiences cannot be repeated: it is necessary to plan right now what will be done after this public health crisis.

In Education, multilateral organizations, States, non-governmental organizations, and educators have been struggling for the universal human right to Education, having in mind equality. This ideal did not emerge after the Second World War: in fact, it emerged from the emphasis on reason and the role advocated for the school by Illustration and the Enlightenment. The revival of human rights (1948) in the United Nations, after the eclipse of the American (1776) and French (1789) Declarations (HUNT, 2008), came to give an official follow-up to these purposes. In the world then, largely destroyed by the armed conflict, the primary concern was to guarantee school places for all. Over time, especially in 1990, 2000 and 2015, United Nations Educational, Scientific and Cultural Organization (Unesco) and the United Nations have designed new horizons of objectives and goals, starting with an Education capable of meeting the minimum learning needs.

The economic recession today prevents the bicycle of the consumer society from standing up, at an increasing speed, in line with the expectation of continued growth. This expectation generates an insoluble equation: you cannot grow infinitely with finite natural resources, which is why the United Nations agreed on sustainable development (cf., e. g., JACKSON, 2017) and Unesco (2015) on inclusiveness in Education. In fact, most countries have grown from an economic point of view, but income is distributed asymmetrically in favor of the wealthier population (ALVAREDO et al., 2018), that is, rivers flow into the sea. Meanwhile, poverty and precarious work tend to increase (STANDING, 2014), since technologically advanced economies adopt management styles to compress and extract the maximum from work (DE GAULEJAC, 2007; DEJOURS, 2019). The goal is to increase productivity and eliminate or transform precarious jobs through robotic automation, artificial intelligence, layoffs, outsourcing and other means. Still, through human or mechanical work, or even hypothetically with hybrid beings, the pillar of wealth still continues to be work. How is it possible to invest in advanced technologies to reduce the number of workers, while management processes also seek to reduce it, is it a mirage to suppose that the 
reduction of jobs and the precariousness of part of them, against the concept of decent work, of the Organization International Labour Office, will be compensated in the long run for new jobs? What will the post-pandemic period be like? The pandemic anticipated future scenarios in the use of technologies and created a gap between occupations: those that admit teleworking and those "in person", where the most vulnerable population is.

In the course of time, educational indicators, in certain places, instead of rising, as before, will tend to decline. However, as the quantities do not exhaust reality, qualitative changes will be introduced. It is unthinkable to return to pre-pandemic Education, because the circumstances are different. There are sensitive, social and economic losses, which do not allow us to "rewind the film". The losses are individual and collective, with probable repercussions on social stratification and the wealth of societies.

Given the dynamism of the changes, this review of documents and literature cannot be limited to the orthodox situations of affirming only what has a critical mass of research, which has been equally approved by peers. In heterodox situations, this study uses sources also considered heterodox, including news from newspapers.

\section{What do theories say?}

Educational achievements have progressed against the background of reformulations of their ends. From expanding access, by opening vacancies even in schools built with tree branches, disarmed in the rainy season, numerous countries have moved towards equal opportunities, equal treatment and equal results (GOMES, 2012). In other words, the lenses go further, because the universality of the human right to Education is less difficult to achieve than equality. Vacancies can simply be linked to the local conditions of the establishments and to the characteristics of the respective students and teachers. In this way, extra and intra-school characteristics interact in order to differentiate one from the other. Housing, income, electronic equipment, books at home, occupation and level of Education of parents or guardians, place for study, possibility of concentration in the home environment, health and their care and domestic amenities contribute positively or negatively to school success, to compose socioeconomic indexes. The more tangible the indicators, the easier they are to be captured by research fishing nets. In contrast, there is a subtle web of inequalities, capable of escaping through the nets of networks: a series of conditions for school-family group interaction, organization and functioning of the school, of existing material and non-material resources, in addition to the cultural capital inherited by students and teachers, the cultural arbitrary embedded in the curricula, social and educational aspirations, school dynamics, family and peer groups. 
The theories of reproduction and many others, linked to the sociological paradigms of consensus and conflict, differentiate the conditions of schooling (GOMES, 2012), their insertion and results. In a way, although the relationships between resources (or "inputs") and results are expressive, the analysis of processes in several layers, the neighborhood, the school, the classroom, curricula and groups of students explains most of the variations (GOMES, 2020).

Thus, a school can select its students among those with the highest socioeconomic and socio-cultural conditions, with better discipline, depending on the residential area, which in turn is linked to other factors. They can become "trash cans" schools in problematic residential areas, of modest socioeconomic status, sub-dwellings and trivialized violence, receiving violent students from other establishments. It may be that the school organizes classes according to the level of student achievement, thereby creating "elite" and "undesirable" classes. Similarly, teachers seek to transfer to other schools in accordance with student conditions and management. Geographic links can be established according to the areas in which the city and countryside differ. Or the school-student-family relationship can be built based on free choice and competition, with "managements" similar to those of companies, always at war over "markets". School units with greater attractiveness, greater fame, more reputable management, higher scores in external evaluations and less disclosure of disciplinary problems tend to attract students with higher aspirations and better performance. The rest of the schools can be closed due to lack of students or doomed to receive the "junk". Like the two dishes on a scale, if the efficiency one weighs more, equality is in disadvantage. But the opposite can happen too.

\section{Fractures exposed}

Covid-19 introduced a new physiognomy in Education, by exposing and expanding social and educational fractures. There are parents and guardians in teleworking and others who are obliged to use public transport and attend in person. There is a myriad of narrow households, where the concentration in studying is less viable and contamination by the virus more likely. There may be a single phone (or none) connected to the internet for sons and daughters at different levels. Television, radio and other devices may be lacking, so it is necessary to consider gaps in Teaching and learning, not only due to the closure of facilities, but also due to difficulties in accessing schooling. If school holidays have more or less favorable consequences for students of different socioeconomic status, imagine the waves of confinement, unemployment, poverty and school difficulties (OLIVEIRA; GOMES; BARCELLOS, 2020), reopening and closing of establishments. 
Unesco (2020) estimated that 24 million students from early childhood to higher Education may no longer return to school. Due to higher costs, the greatest risks occur in higher Education, followed by early childhood Education, with a supposed loss of $3.5 \%$ of the enrollment concerning the first one (less 7.9 million) and $2.8 \%$ concerning the second one ( 5 million). The cohort of disadvantage fall on the most vulnerable populations, such as women and girls, ethnic minorities, people with special needs, less favored social strata, inhabitants of rural areas and those who did not have access to distant learning (DL). Women and girls need to work inside or outside the home and take care of younger children. Because of these conditions, they can be compelled to child marriage, in order to have fewer mouths to feed in the household. In developed countries, with structural racism, ethnic minorities are more likely to be infected, with higher mortality (BENITEZ; COURTEMANCHE; YELOWITZ, 2020).

According to the Program for International Student Achievement (Pisa) in 2018 (OECD, 2020a), 15-year-olds, who had already undergone socio-educational filters since the beginning of schooling, had different levels of access to computers internationally and intra-nationally. In Indonesia, only 34\% of the students surveyed had it. In the United States, virtually all schools considered favored provided computers, but the same was only true for $75 \%$ of the students at the disadvantaged schools. In Peru, the most and least favored school units, respectively, had availability for $88 \%$ and $17 \%$ and in Mexico, $94 \%$ and $29 \%$. The total number of teachers considered to be prepared to integrate electronic devices into their classes globally covered $65 \%$ of the students. Those with enough time to prepare classes with information and communication technologies corresponded to $60 \%$ of the students. However, teachers with this availability in Japan only involved $10 \%$ of the students, pointing out international inequalities.

These disparities, mirroring the concentration of income, translate into different conditions of access to remote Education, including in the so-called rich countries. For the less affluent population, in addition to not attending school, the closure of schools means starvation aggravated by the economic recession, unemployment and precarious work: of the 30 million children in the United States who consume school meals, 22 million, due to low income, qualified for free or lower price meals (NIERENBERG; PASICK, 2020).

As for distant learning, a survey published in Chile, with a representative national sample of households, showed that $84.3 \%$ of students in basic and high school in the upper income quintile received classes by videoconference, in contrast to only $60.6 \%$ in the quintile of lower income. As the school system is clearly stratified, 
the proportions in paid private schools and in public municipal establishments, respectively more and less well-off, were $89.9 \%$ and 61.2\% (SEPÚLVEDA, 2020). In general, students' connection and study time decreased, with consequences on learning, not to mention the social and emotional aspects.

Young students are not immune to the virus, but children have different characteristics. In fact, the European Center for Disease Prevention and Control (2020) found out less than $5 \%$ of cases of contamination related to people till 18 years old. These have milder symptoms, different courses of infection and immune response (WEISBERG et al., 2021); however, they transmit the virus like adults do and can carry it to other generations at home. In Luxembourg it was found that the reopening of schools did not contribute to speeding up the spread of Covid-19, as the percentage of positive cases in the 0-9 and 10-19 age groups was much lower than $20 \%$ of the general population (LAMBERT, 2020). This, however, did not prevent the adoption of quarantine by certain classes and schools. Finally, if children are not immune to the virus, they are also not a major source of contamination.

\section{Crisis within the crisis}

The social sciences confirm the proverb "the rope breaks on the weakest side". In fact, the most vulnerable groups receive the greatest burden from a social, economic, educational and cultural point of view. Economic recession, mass unemployment, greater job insecurity affect those who have less. Xue et al. (2020) refer to the hidden pandemic, with damage to psychological health, such as stress, anxiety, depression and increased violence against women and children.

Women and girls receive the greatest burden in domestic work, with a substantial increase in unpaid activities, such as the care of children and the elderly. At the same time, women are the majority of health and Education personnel, therefore, the ones most in demand. The United Nations (2020) recommended, among other measures, the continuity of institutional care for the elderly, the expansion and provision of inclusive protection for caregivers, the expansion of access to licenses to care for the family, the transfer of financial support to the hands of women, and the expansion of access to family leave licenses.

A sample of Italian women indicated that workers with personal attendance at work and mothers of children up to five years of age were the most affected, with an increase in the time spent on household tasks (DEL BOCA et al., 2020). In the United States, data from February to April 2020 from the US Current Population Survey showed that, with the closure of schools and early childhood Education institutions, married mothers of children aged one to five years, in April, had to 
reduce 6,2 hours of work weekly more than their husbands, while the mothers of children aged 13 to 17 had to decrease 4,5 hours more than their spouses (COLLINS et al., 2020). In a period of unemployment, there was probably a decline in family income, especially for women, with risks of job loss and serious long-term career compromise. A possible factor was the higher male pay. Women, largely in the social sectors, in the so-called pink ghetto occupations, earn less, and thus can choose to reduce their lower wages to safeguard their husband's.

Therefore, the pandemic also has regressive effects on female independence. With the closure of schools, in addition to the greater unpaid work, women and girls were subjected to violence. Babvey et al. (2020) analyzed in New York City, in March and April 2020, conversations on a social network and searched for blogs and news aggregators about hate content, cyberbullying and intra-family violence. The citations of cyberbullying multiplied, in addition to the increase in violence in the households, just when the protective services had a disrupted functioning. Extending to data from 15 countries, including Brazil, they found a significant increase in abusive messages from confinement, with the main topics being intimate partner abuse, physical, sexual and child abuse.

For their part, Tener et al. (2020) carried out an investigation on intra-family sexual abuse of children. Financial and emotional difficulties made them vulnerable, especially with schools' closure. Previous epidemics, such as Ebola in West Africa, have shown, apart from mental and emotional health disorders, the greatest victimization of children and adolescents. It was estimated that $10 \%$ to $20 \%$ of them had greater exposure to violence, mainly girls. These were subject to greater coercion, exploitation, sexual abuse and an increase of almost $11 \%$ probability of unplanned or unwanted pregnancies (WORLD BANK, 2020).

As for cyberbullying, an interview by Justine Athan, general director of the e-Enfance association in France (DUNEAU, 2020), reported that the occurrence became commonplace before the pandemic, covering almost all schools and high schools, with more frequent authorship and victimization of the group from 13 to 14 years old. With the suspension of classes, there was a great reduction, while violence on the internet grew, establishing undesirable contacts with adults, in particular by teens. According to the complaints, the Association found increasing cases of sexual harassment, blackmail and obtaining sensual photos of girls and boys.

\section{Is there success on distance learning?}

The advent of distance learning has given rise to concrete hopes for democratization and quality requirements. However, its balance in the pandemic is not flattering, 
due to the difficulty, haste, improvisation and presence of an aggressive market selling equipment and services. The ideals of Harold Wilson's labour government in the United Kingdom are long gone when he founded Open University in 1969. If the north changes, the route also changes.

Reimers and Schleicher (2020) reported a convenience sample survey of teachers and school board members at the beginning of the pandemic in 59 countries. The priority was to continue schooling through computers, the internet, radio and television. The median of the students who could access the entire curriculum was $51.4 \%$ and those who had a "good level" of access were $11.7 \%$. At that time, the median number of students able to access the curriculum was only $66.7 \%$ and, with the support of teachers, $53.5 \%$. The Education Teaching resources used were those existing online in $95.8 \%$ of the cases; online Education Teaching by the same teachers of the students, $92.8 \%$; television, $95.8 \%$, and radio, $92.8 \%$. Let us envision the regions that have no signal or electricity. Thus, there are heroic efforts, still far from providing Education for all.

Let us move on to Chile, the country that usually leads the Pisa scores in Latin America. Organizations did some research on the learning balance during the pandemic. Data are limited because they are collected remotely, tending to eliminate the least socially privileged. Said (2020) informs us of the results of the survey with the students: $24 \%$ reported not having learned anything; $20 \%$ learned very little and only $5 \%$ "learned a lot". For $64 \%$ of them, classes were more boring. After the pandemic, they considered valuing the autonomy they had achieved (50\%), 47\% wanted shorter classes and, in general, valued the characteristics of a more humane Education. In fact, for the teachers, the most effective strategies were personalized tutorials by phone or video call. In other words, Education is likely to have less submissive and more critical students after the crisis, thus requiring changes. Selling technology and services can be a great market opportunity for companies, although it seems that the digital native generation has not been satisfied with the technological sophistication. The variations on opinions followed the schools' socioeconomic hierarchy, that is, the most favoured felt less behind, while the least favoured were further behind. The big problem is that a country does not live only on elites.

Suppose that the socioeconomically more affluent students are much better served. Still in Chile, an anthropologist conducted an online research, in September 2020, among students, parents and guardians of the most expensive schools in eastern Santiago. These anticipated the holidays to prepare themselves better for the emergency; however, data again cast doubt on the relationship between 
financial resources and results. There was a constant dissatisfaction with the schools' lack of empathy: the educational response was concentrated on parents and guardians, without considering the conditions of the recomposed families, of the children and adolescents with difficulties and of the obstacles represented by the simultaneous work, even at home, and the orientation of their sons and daughters. The establishments did not ask if there was any equipment at home and which equipment was available, they adapted very slowly and, of course, establishments did not lower monthly fees. In the first trimester, an exhausting amount of student tasks were prescribed for parents to guide. The help of the institutions was limited to the personal effort of the teachers, without institutional support. These brought together smaller groups of students, addressed them and, with that, worked until $11 \mathrm{pm}$. For parents, in academic terms, it was a lost year, a "year in parentheses" (SEPÚLVEDA, 2020).

In Portugal, a consumer protection association pointed out that only three out of ten parents were satisfied with distance learning in the first cycle, corresponding to primary school. The support for children with special needs received the most negative evaluation. The most mentioned positive aspects were the videoconference classes and the videos recorded by the teacher. As for the students, only one-third said it was easy to focus on online classes, while only $81 \%$ completed all the proposed tasks (SAPO, 2020). It seems, therefore, a dystopia that machines can teach to mechanized people. Certainly, for this reason the American Academy of Pediatrics (2020) declared that schools are essential for the development and well-being of children and adolescents and for reducing ethnic and social inequalities. Therefore, school standards need to be flexible, practical and viable - their goal is to mitigate inequalities, not to eliminate the virus.

Indeed, Gupta and Jawanda (2020) summarized the positive and the negative aspects of Covid-19 for children, in literature. The former, among others, involved new educational skills, personal development, building of self-confidence, awareness of an unknown disease, greater family life and the development of humanitarian feelings and empathy. The latter are led by Education: total lack of it, loss of quality, emphasis on results, deepening of the gap between rich and poor. But also, anxiety and frustration in the face of the future, lack of physical activity, social isolation, cyberbullying, sexual exploitation, substance abuse, abuse and child labour.

\section{How about the educators?}

Under the outlined conditions, ready and highly qualified responses could not be expected from the group of teachers. Research by the Organization for Economic 
Co-operation and Development-OECD (2020b) highlighted the difficulties, noting that the inclusion of technologies in initial and continuing teacher Education is positively related to their use in Teaching and learning. Furthermore, schools that encourage staff to take new initiatives offer fertile soil for integrating technologies into Teaching practice.

At least in France, a narrow survey by Institut Français de l'Education (2020) revealed that almost $70 \%$ of teachers, from maternal to higher Education, described their material conditions during confinement as comfortable. Less than $40 \%$ of primary and secondary school teachers felt at ease at the beginning, but the proportion increased to $60 \%$ at the end of the first wave of the pandemic. In contrast, the workload increased to $71 \%$ of the teachers, while the most difficult task for $77 \%$ was to monitor student work.

These new challenges affect the career, with more work, due to the frequent contacts on the internet, in extended hours, with the same or less remuneration. As it is well known, the cost per student of distance learning is much lower than that of face-to-face Education, hence the participation or exclusivity of the first can burden the Teaching group, including subtracting jobs, as in the case of teachers investigated in France and in Chile.

This web of relationships involves a subtle social contract between school, teachers and society (CRAHAY, 2002). Belonging to a non-material culture, its effects do not cease to be felt, including in terms of well-being or ill-being, when its rules are unilaterally violated, often under the false motto that the ends justify the means. In this sense, there is a dystopia in the sense of "digitizing" school and/ or "un-schooling" society. Criticism towards Illich, in the 1970s, warned against an increase in social inequalities, due to differences in resources, heritage and socio-cultural environments.

Lower costs and the search for efficiency are, in certain cases, greater temptations. One example was Mexico's "pragmatism", which delivered much of its needs to a big data giant. It planned a one-week "training" for half a million teachers. Obviously, a week was insufficient and, therefore, extended to the end of the year. What is worse is that the gigantic company has applied its management form, proposing to make available to teachers more than 12,700 class plans for basic Education, more than 2,000 learning assessment programs and programs of other transnational companies. Thus, the Teaching staff was reduced to a group of technicians specialized in choosing materials. This radical redefinition of role has caused problems in a multilingual and multicultural country that 
is permeated by social and regional inequalities. Big data corporate culture and school culture clashed, when cultural shocks cannot be underestimated. A survey among teachers from the capital found out that only $25 \%$ of the students had a computer connected to the internet at home and $75 \%$ had parents who went out to work. Only $1.7 \%$ of teachers declared being capable of managing Teaching design programs. However, they knew their students, their languages and customs and they knew their main needs. They certainly did not feel well as guinea pigs. Since computers were insufficient, television and radio programs turned out to be indispensable, and later translated into indigenous languages. Even so, household resources are restricted and the signal is unable to reach all states (DÍAZ-BARRIGA, 2020).

For this reason, this was yet another window of opportunity lost in the failed procession between technology and school relationship, in the Southern Hemisphere. At any latitude, it is necessary to analyze and consider society and culture deeply, instead of depleting the role of the Teaching profession in what it is most relevant: the human aspects. Situations like this one leave memories for a long time, they delegitimize and delegitimize other initiatives also. Wanting to "save" the school year at all costs, it may have largely led to its loss.

\section{Costs, benefits and losses}

Like the two sides of a coin, Education has both public and private costs and benefits. Even if a child has free school, material, food and transportation, costs remain for the family group, such as the one concerning the opportunity to study and of not working. This is one of the biggest points of concern in recessionary times, as, for example, in a region of India, where children leave school to collect 5-6 kg of mica shavings, bought by luxury industries for 50-60 cents of euro per day (MAIA, 2020). On the other side of the coin, Education has both public and private benefits, that is, losses also contribute to the nation's economic decline.

In an optimistic scenario, the adjusted learning years will be reduced by $3 \%$ and, in a pessimistic scenario, by $11 \%$, while Pisa scores will shrink by $1 \%$ to $6 \%$, respectively (AZEVEDO et al., 2020). Is that little? No, around these central trends the variations reflect more and less favoured countries, regions and populations, driven by a sudden downward spiral typhoon. Strictly speaking, almost all or most participant countries have gone backwards, even the wealthiest; however, it is worse for the most vulnerable. For the reconstruction, some have more resources than others. Two major social processes operate concurrently: differentiating competition, under the aegis of individualism and corporatism, and cooperation, insofar as one is aware of the interdependence and value of the 
common. It is hypocritical to deal with social cohesion without taking care of the common good: there can be no lack of compensatory actions, because those who are at the end delay those at the front. An overly competitive society can fall apart and the common oikos is ruined for everyone. All of this arises from the need for actions already planned for the post-pandemic period.

It is necessary to selectively list items for reducing and increasing educational costs in the pandemic and after it (Table 1), from the point of view of school units.

Table 1 - Breakdown of the main items for reducing and increasing educational costs

\begin{tabular}{|c|c|}
\hline Cutback & Increment \\
\hline $\begin{array}{l}\text { Lower maintenance costs } \\
\text { when schools are closed. }\end{array}$ & New costs for reopening schools in the pandemic. \\
\hline $\begin{array}{l}\text { Reduction of students } \\
\text { (through dropout and } \\
\text { absence). }\end{array}$ & $\begin{array}{l}\text { Campaigns, censuses and surveys for re-enrollment. } \\
\text { Reduction of the number of students per class to maintain } \\
\text { physical distance. }\end{array}$ \\
\hline $\begin{array}{l}\text { Minimization of fixed and } \\
\text { variable costs. }\end{array}$ & $\begin{array}{l}\text { Further saved resources to cover new and fundamental costs: } \\
\text { - support and continuing Education of the group of teachers; } \\
\text { - psychological support for teachers and students; } \\
\text { - programs for the recovery and acceleration of learning; } \\
\text { - purchase and maintenance of equipment; } \\
\text { - reduction and elimination of costs for families and students; } \\
\text { - financial transfers to families in order to overcome child } \\
\text { labor (to offset opportunity cost); } \\
\text { - other costs. }\end{array}$ \\
\hline $\begin{array}{l}\text { Policies to combat public } \\
\text { deficit: form to shrink social } \\
\text { spending, privatization and } \\
\text { quasi-market processes. }\end{array}$ & Need to preserve educational funds. \\
\hline
\end{tabular}

Source: Own elaboration, 2020

Many developing countries lost ground in improving Education in general, particularly basic Education. For this reason, it is necessary to advance more quickly, which places us in front of the square of the circle. If, on the one hand, economic policies value formulas that reduce social spending, on the other, Education and health have significant social and economic effects, projecting disputes in the arenas of public budgets. Budget cut policies need to be careful to avoid boomerang effects. For example, remote learning can reduce costs per student; however, if used with this central objective, without considering conditions and quality, it can have negative effects on learning and Education. The losses in this regard are incomparably greater than possible savings. 


\section{How about after the pandemic?}

Multilateral organizations converge in the sense that the time to plan for the future has begun. This recommendation applies to almost every country, as well as the following observations in this text. Education cannot be seen according to the play of ideological lenses. It cannot be reduced to the rationalist mechanism of modernity, comparable to the analogic clock of an old railway station. For purposes and means, it also does not resemble a company designed to produce goods or provide services and generate profits. As mentioned before, the company-state can dominate politics, with the election of anti-politics who propose to make the public organization efficient, with oiled and agile gears (MUSSO, 2019). Likewise, "management revolutions" do not work to increase productivity by ruining people's organizational climate and mental health. The complex reality does not fit into simplistic forms: what can have positive results in one field, if really positive, may be inadequate for others.

In any case, people interact, they are not reduced to machines. As much as stereotypes persist, Education is not an automobile assembly line: it is a social area capable of dealing with values, attitudes, behaviors, interactions between people and groups. What can work in engineering may not work in Education. Let us see: in addition to the fact that a human being is endowed with will, conscience and self-awareness, the Education to form this human being deals with values, such as right/wrong, true/false, beautiful/ugly, desired/unwanted futures. So, it has purposes, which refers to philosophy. This, out of ignorance, or disdain, tends to remain shrouded in mist, more or less amorphous.

Education also deals with human beings, their thinking, feelings and acting. You do not learn if you lack desire, if you are not confident in your own ability to learn and if you do not trust in the fact that it is worth learning, which refers to psychology. On the other hand, learning is indispensable, but not enough: Education is much more: learning to know, to do, to coexist and to be (DELORS et al., 2003). Thus, the "learning deficit" in the world is deploring; however, it is only one side of the question of something bigger. Here you have to go to the heart of the matter: there is no point in scratching the surface like crabs.

Education has somewhat contradictory missions: transmitting the socio-cultural heritage, promoting citizenship and equality, being a driver of social change, liberating and preparing for unknown futures. The new generations are compared to arrows launched by the bows of the educators towards the mansion of tomorrow, where the current generation will never inhabit (GIBRAN, 2011). Connecting coherently to other options, Education therefore needs to have the light of sociology 
and other social sciences. In fact, Education is not a singular path, but a square of theories and practices, towards where a plurality of streets flow.

Having this in mind, the proposals are oriented towards evaluating what has been done, what has been learned, recovering what has not been learned and by not repeating the same mistakes; on the contrary, doing better and differently. If the use of distant learning incurred in a flow of errors, if it lacked quality, it is not the case of throwing it all away, but of seeing it mainly as Education, keeping the awareness that Education requires personal presence. If learning has diminished, it is worth worrying about what is around it: people often impoverished, excluded, with psychological difficulties due to the long pandemic, family groups in conflict or broken, physical health consequences, students full of uncertainty about the future, who they are, what they are going to do. A teacher is not a simple instructor: he or she is an educator. At the same time, nobody can expect that a teacher is a superhero but rather a tired human being, under tensions and doubts. In this sense, to support students and their family groups, a teacher also needs support, since no one is able to offer what he or she does not have.

More than office plans, post-pandemic efforts need to be combined with the living forces of the community and society, to be heard and to participate. The cooperation between society and the State must take the palm of minor dissensions. If transformations created the networked society, it is also necessary to think and act in a network.

From the point of view of resources, ensuring equality implies explicit actions, focusing on the least favoured. Education took several steps backwards, winds and rains devastated part of what was built in a hard way in the last decades. None of this will return gracefully: action must be taken on behalf of those who have most fallen behind. And move on, with the rectification of the numerous mistakes made.

Injecting financial resources does not necessarily imply obtaining the best results on the other side of the supposed box. To preserve the minimum for each student and to use this minimum well is to guarantee a certain standard of equality. Against the current of austerity forms, it is necessary to be aware of the scarcity of resources and dedicate as much as possible to the social sectors. In this sense, the preservation of minimum resources for Education is a point of honor for historical-social ties and for the uplifting of economies. In this way, Brazil has arrived at a simple formula of the so-called lost decade in Latin America, the 1980s: the bonding of minimum funds to tax collection, according to the winning proposition of Senator João Calmon. 
To that end, populism and demagogy are not constructive, the same way are not political personalities, supposedly successful in business, who propose themselves to manage the State as they manage their companies. State and a company are different. Equally, erosive competition between political currents does not contribute to elevating nations.

Instead, the pact for the common good is needed, the convergence around joint goals, the agreement around the survival of the world and nations. It can be objected that these agreements are "utopian": in fact, History records dark periods and others in which, due to risks or other reasons, consensus is reached to preserve the general and, later, dispute the particular, because the particular does not survive without the general. Almost most of us are in a tunnel that, like any tunnel, has an end. Finitude is a mark of the human being and of the nature in which he lives. For this very reason, the future is being prepared from the present. 


\section{Educação durante e depois da pandemia}

\section{Resumo}

A Educação, durante o período da pandemia da Covid-19, frequentemente recebeu tratamento improvisado e irrealista, por isso cumpre, desde já, planejar o período pós-pandêmico. Conforme a análise da literatura e da documentação, escancararam-se as fraturas sociais, inter e intranacionais existentes, detectadas pelas teorias. Além da Covid-19, geraram-se crises dentro da crise, como o empobrecimento e a violência. As perdas tendem a ser gerais, porém, os menos favorecidos foram os mais prejudicados. Cumpre não repetir os erros nem restaurar o passado sem mudanças, pois as circunstâncias são outras. Além do déficit de aprendizagem, é preciso recuperar a Educação em suas diversas finalidades. Para tanto, cabe apoiar educadoras.es, estudantes e famílias, enfocando os menos privilegiados, com a participação das forças vivas da comunidade e da sociedade.

Palavras-chave: Desigualdades Educacionais. Pandemia. Saúde e Educação. Desenvolvimento da Pessoa Humana. Família.

\section{Educación durante y después de la pandemia}

\section{Resumen}

La Educación en esta pandemia ha sido frecuentemente objeto de políticas improvisadas e irrealistas. Esta es la grande razón para, en el presente, planear el periodo posterior. Además del Covid-19, otras crisis se desarrollaron, como el empobrecimiento y la violencia. En general, la población tiene pérdidas, pero los menos privilegiados suportan las más onerosas cargas. En adición al déficit de aprendizaje, es urgente recuperar la Educación en sus múltiples finalidades y objetivos. Así, es importante el apoyo a educadores, estudiantes y familias, con foco especifico en los menos privilegiados, contando con la participación de las fuerzas sociales de la comunidad y la sociedad.

Palabras clave: Desigualdades Educativas. Pandemia. Salud y Educación. Desarrollo Humano Personal. Familia. 


\section{References}

ALVAREDO, F. et al. World inequality report 2018. Paris: World Inequality Laboratory, 2018.

AMERICAN ACADEMY OF PEDIATRICS. Covid-19 planning considerations: guidance for school re-entry. Itasca; 2020. Available from: https://services.aap.org/en/pages/2019-novel-coronavirus-covid-19-infections/ clinical-guidance/covid-19-planning-considerations-return-to-in-person-educat ion-in-schools/. Access in: 20 out. 2020.

AZEVEDO, J. et al. Simulating the potential impact of Covid-19 school closures on schooling and learning outcomes. Washington, DC: World Bank, 2020.

BABVEY, P. et al. Using social media for assessing children's exposure to violence during the COVID-19 pandemic. Child Abuse \& Neglect, [s. 1.], 2020. https://doi.org/10.1016/j.chiabu.2020.104747.

BENITEZ, J.; COURTEMANCHE, C.; YELOWITZ, A. Racial and ethnical disparities in COVID-19: evidence from six large cities. Journal of Economics, Race, and Policy, [s. 1.], v. 3, p. 243-61, Dec. 2020. https://doi.org/10.1007/s41996-020-00068-9

COLLINS, C. et al. Covid-19 and the gender gap in work hours. Geneva: World Health Organization, 2020.

CRAHAY, M. Poderá a escola ser justa e eficaz? Da igualdade das oportunidades à igualdade dos conhecimentos. Lisboa: Piaget, 2002.

DE GAULEJAC, V. A gestão como doença social: ideologia, poder gerencialista e fragmentação social. Aparecida: Ideias \& Letras, 2007.

DEJOURS, C. A banalização da injustiça social. 7. ed. Rio de Janeiro: Fundação Getúlio Vargas, 2019.

DEL BOCA, D. et al. Women's and men's work, housework and childcare, before and during COVID-19. Review of Economics of the Household, [s. 1.], v. 18, p. 1001-1017, Dic. 2020.

DELORS, J. et al. Educação: um tesouro a descobrir. 2. ed. São Paulo: Cortez; Brasília, DF: MEC, 2003. 
DÍAZ-BARRIGA, A. La escuela ausente, la necesidad de replantear su significado. In: AGUILAR, J. et al. Educación y pandemia: una visión académica. Ciudad de México: Instituto de Investigaciones sobre la Universidad y la Educación, Universidad Nacional Autónoma de México, 2020. p. 19-29.

DUNEAU, C. Le cyberharcèlement scolaire s'est complètement banalisé. Le Monde, Paris, 7 nov. 2020. Available from: https://www.lemonde.fr/pixels/ article/2020/11/05/le-cyberharcelement-scolaire-s-est-completement-banali se_6058665_4408996.html. Accesso in: 7 nov. 2020.

EUROPEAN CENTRE FOR DISEASE PREVENTION AND CONTROL - ECDC. Covid-19 in children and the role of school settings in COVID-19 transmission. Solna, 6 Aug. 2020.

GIBRAN, K. O profeta. Rio de Janeiro: Nova Fronteira, 2011.

GOMES, C. A educação em novas perspectivas sociológicas. 4. ed. São Paulo: EPU; Rio de Janeiro: Gen, 2012.

GOMES, C. Escola de qualidade para todos revisitada: desfolhando as camadas da cebola. Ensaio: Avaliação e Políticas Públicas em Educação, Rio de Janeiro, v. 28, n. 109, p. 843-862, out./dez. 2020. https://doi.org/10.1590/s0104-40362020002802958

GUPTA, S.; JAWANDA, M. The impacts of COVID-19 on children. Acta Paediatrica, Oslo, v. 109, n 11, p. 2181-2183, July 2020. https://doi.org/10.1111/apa.15484

HUNT, L. Inventing human rights: a history. New York: W.W. Norton, 2008.

INSTITUT FRANÇAIS DE L'ÉDUCATION. Effets du confinement sur l'activité des enseignants et des professionnels de l'enseignement: premiers résultats. Lyon: Université de Lyon, 2020.

JACKSON, T. Prospérité sans croissance: les fondations pour l'économie de demain. 2. ed. Louvain-la-Neuve: De Bocck Supérieur, 2017.

LAMBERT, F. Propagation du virus ? 'L'école n'y est pour rien'. L'Essentiel, Luxemburgo, 12 nov. 2020. Available from: http://www. lessentiel.lu/fr/luxembourg/story/10556487?utm_source=newsletter\&utm_ medium=email\&utm_content=story_main\&utm_campaign $=$ newsletter. Access in: 12 nov. 2020. 
MAIA, A. M. Na Índia, crianças-mineiras trocam a infância por aparas de mica. Público, Lisboa, 14 ago. 2020. Available from: https://www.publico. pt/2020/08/14/p3/fotogaleria/na-india-criancas-mineiras-trocam-a-infancia-por -aparas-de-mica-402138. Access in: 14 ago. 2020.

MUSSO, P. Le temps de l'État-Entreprise. Paris: Fayard, 2019.

NIERENBERG, A.; PASICK, A. Schools are for lunch, too. New York Times, Coronavirus briefing, New York, 4 set. 2020. Available from: https://www.nytimes.com/2020/09/04/us/coronavirus-schools-briefing-lu nch-along-with-learning.html. Access in: 26 fev. 2021.

OECD. Learning remotely when schools close: how well are students and schools prepared? Paris, 2020a. Available from: https://read.oecd-ilibrary. org/view/?ref=127_127063-iiwm328658\&title=Learning-remote ly-when-schools-close. Access in: 19 nov. 2020.

OECD. Teachers' training and use of information and communications technology in the face of the COVID-19 crisis. Paris, 2020b. Available from: https://www.oecd-ilibrary.org/docserver/696e0661-en.pdf?expires $=16058135$ 10\&id=id\&accname $=$ guest\&checksum=7E00DE5128B971ED0994B4832311 3E5. Access in: 19 nov. 2020.

OLIVEIRA, J. B.; GOMES, M.; BARCELLOS, T. A Covid-19 e a volta às aulas: ouvindo evidências. Ensaio: Avaliação e Políticas Públicas em Educação, Rio de Janeiro, v. 28, n. 108, p. 555-678, jul./set. 2020. https://doi.org/10.1590/s0104-40362020002802885

REIMERS, F.; SCHLEICHER, A. Schooling disrupted, schooling rethought: how the Covid-19 pandemic is changing education. Paris: OECD, 2020. Available from: https://globaled.gse.harvard.edu/files/geii/files/education continuity_v3.pdf. Access in: 19 nov. 2020.

SAID, C. Uno de cada cuatro escolares dice que no ha aprendido nada durante la pandemia. La Tercera, Santiago, 11 nov. 2020. Available from: https://www. latercera.com/nacional/noticia/uno-de-cada-cuatro-escolares-dice-que-no-ha-a prendido-nada-durante-la-pandemia/76WZKAMTNFHPDISJ2I27VDHXHU/. Access in: 11 nov. 2020.

SAPO. Estudo da Deco revela famílias pouco satisfeitas com ensino a distância no $1^{\circ}$ ciclo. 26 ago. 2020. Available from: https://24. sapo.pt/atualidade/artigos/estudo-da-deco-revela-familias-po uco-satisfeitas-com-ensino-a-distancia-no-1-o-ciclo. Access in: 26 ago. 2020. 
SEPÚLVEDA, P. Clases on line en los colegios más caros de Chile y la queja de los apoderados. La Tercera, Santiago, 12 nov. 2020. Available from: https://www.latercera.com/que-pasa/noticia/clases-on-line-en-los-colegiosmas-caros-de-chile-y-la-queja-de-los-apoderados-hay-que-correrno-bajaron-1 a-mensualidad-han-sido-lentos/ZQCYXD6EMFFBNMPTKLRNY6UETI/. Access in: 12 nov. 2020.

STANDING, G. Le précariat: les dangers d'une nouvelle classe. Paris: Les Éditions de l’Opportun, 2014.

TENER, D. et al. How does COVID-19 impact intrafamilial child sexual abuse? Comparison analysis of reports by practitioners in Israel and the US. Child Abuse \& Neglect, 104779, 2020. https://doi.org/10.1016/j.chiabu.2020.104779

UNESCO. Educação 2030: Declaração de Incheon: rumo a uma educação de qualidade inclusiva e equitativa e à educação ao longo da vida para todos. Paris, 2015. Available from: https://www.catedraunescoeja.com.br/ upload-files/marco_de_acao_2030_incheon.pdf. Access in: 10 nov. 2020.

UNESCO. How many students are at risk of not returning to school? Paris, 2020. Available from: https://www.magisnet.com/wp-content/ uploads/2020/08/informe-de-la-Unesco.pdf. Access in: 19 nov. 2020.

UNITED NATIONS. The impact of COVID-19 on women. Policy Brief, 2020. Available from: https://www.un.org/sites/un2.un.org/ files/policy_brief_on_covid_impact_on_women_9_april_2020.pd. Access in: 19 nov. 2020.

WEISBERG, S. et al. Distinct antibody responses to SARS-CoV-2 in children and adults across the COVID-19 clinical spectrum. Nature Immunology, New York, v. 22, p. 25-31, 2021. https://doi.org/10.1038/541590-020-00826-9

WORLD BANK. The Covid-19 pandemic: shocks to education and policy responses. Washington, DC, 2020. Available from: https://www.worldbank. org/en/topic/education/publication/the-covid19-pandemic-shocks-to-educa tion-and-policy-responses. Access in: 19 nov. 2020.

XUE, J. et al. The hidden pandemic of family violence during COVID-19: unsupervised learning of tweets. Journal of Medical Internet Research, Toronto, v. 22, n. 11, e24361, Nov. 2020. https://doi.org/10.2196/24361 


\section{Information about the authors}

Candido Alberto Gomes: Ph. D. in Education, University of California, Los Angeles. Professor of Education and Directo of the Research, Innovation and Development Center, Instituto de Estudos Superiores de Fafe, Portugal. Contact: candidoacg@gmail.com

iD https://orcid/org/0000-0001-8498-3785

Susana Oliveira e Sá: Ph.D in Education and post-doctoral Studies at University of Minho, Portugal. Associate Professor at the Instituto de Estudos Superiores de Fafe, Portugal. Contact: susana.sa@iesfafe.pt

iD https://orcid.org/0000-0003-1339-5745

Enrique Vázquez-Justo: Ph.D, Santiago de Compostela University, Spain. Professor and President of the Instituto de Estudos de Fafe, Portugal. Contact: presidente@iesf.pt iD https://orcid.org/0000-0001-7627-6386

Cristina Costa-Lobo: Ph. D., University of Coimbra, Portugal. Researcher at the UNESCO Chair in Education for Social Justice and at the UNESCO Chair in Youth, Education and Society. Educational Innovation Director and Coordinating professor, Instituto de Estudos Superiores de Fafe, Portugal. Contact: cristinalobo@iesf.pt

iD https://orcid.org/0000-0003-4459-8676 